\title{
Completeness Analysis of Completeness Filling and Time of Returning The Medical Record for Inpatient Patients at Regional General Hospital of Makassar City
}

\author{
Vinani Fajariani, ${ }^{1}$ Noer Bahry Noor, ${ }^{1}$ Hasnawati Amqam $^{2}$ \\ ${ }^{1}$ Department of Hospital Management, Faculty of Public Health, Hasanuddin University, \\ Indonesia \\ ${ }^{2}$ Environmental Health Section, Faculty of Public Health, Hasanuddin University, Indonesia \\ Received: October 26, 2020 \\ Revised: November 5, 2020 \\ Accepted: November 8, 2020
}

\begin{abstract}
At Makassar City Hospital, one of the service indicators that has not been achieved is in incomplete medical record files and medical record files that are returned more than $2 \times 24$ hours after service. This study aims to analyze the implementation of the completeness of filling in and the timeliness of returning inpatient medical record files at the Makassar City Hospital. This type of research is mixed methods research. The study design used a crosssectional approach. The study was conducted in September - October 2020. The results showed that the implementation of completeness of filling in and the timeliness of returning medical record files was still low, this has led to the accumulation of medical record files in the treatment room and delays in returning the files of inpatients to the medical record installation of the City Hospital Makassar. Training on the implementation of medical records has not been comprehensive for all officers at the Makassar City Hospital. The result of the delay in returning the documents is the delay in payment of insurance claims to the hospital. Accumulation of medical records in the treatment room from incomplete medical records and returned to the treatment room. Health workers who forget to fill in complete medical records are only given a sanction in the form of a warning during a meeting with the medical committee. Availability of SOP on filling and returning medical record files at the hospital. The facilities and infrastructure in the implementation of medical records are still insufficient for medical record employees at Makassar City Hospital. It is recommended that the hospital improve the implementation of the completeness and timeliness of returning medical record files, provide incentives or rewards for completing filling in, increase the number of computers and expand the room in the medical record installation, and review the medical record format at Makassar City Hospital
\end{abstract}

Keywords: Medical Records, Completeness of Completeness, Timeliness, Inpatient

\section{Introduction}

The medical record is used as a reference for the next patient, especially when the patient is treated again, the patient's medical record must be ready when the patient is treated again. Health workers will find it difficult to carry out actions or therapy before knowing the history of the disease, action or therapy that has been given to the patient in the medical record document. The important thing in medical record documents is their availability when needed and the completeness of their filling. Completeness of filling out medical record documents by health workers will make it easier for other health workers to provide action or therapy to patients. In addition, it is also a data source in the medical record section in data processing which will then become useful information for management in determining strategic steps for health service development (Hatta, 2008). 
One of the supporting factors in the processing of medical record files is the return of the patient's medical record files who have received health services from the inpatient unit. Returning the medical record file is the beginning of processing the patient's medical record file. The sooner the files are returned to the medical record unit, the faster the processing of medical record files will be carried out which can affect the quality of the medical record unit's performance. Timely return of medical record files is one effort that can be made to create quality medical record management (Michaud et al., 2006; Winarti, 2013; Nugraheni \& Hendratna, 2019).

Delay in returning medical record files for more than $2 \times 24$ hours can hinder services, patient data processing activities and reporting activities. In addition, delays in returning medical records will have an impact on data processing, submitting insurance claims and hampering service to patients (Winarti, 2013). Regarding the accuracy of returning medical record files, it has also been explained to the Ministry of Health of the Republic of Indonesia in 2006 regarding the Guidelines for Hospital Medical Record Administration and Procedures, the standard for returning patient medical record files home is a maximum of $2 \times 24$ hours.

Based on an initial interview conducted in February 2020 with the head of medical records at the Makassar City Hospital with questions about problems in the medical record, the head of medical records stated that one of the indicators of service that has not been achieved is in the incomplete medical record file and the return of the record file. medical service that exceeds 2x24 hours after service. The head of medical records explained the delay in returning the medical record files was because there were still gaps in the files so that health workers delayed returning to the medical record installation. Even today, delays in returning medical records often occur, which take a maximum of 2 months.

At initial observation, it was found that in almost all inpatient care rooms there were piles of medical records of patients who had returned home. During the interview with the nurse, it was discovered that the medical records did not only belong to patients who had just been discharged, but also those of patients who had been discharged for more than three days.

The highest percentage of medical record document returns at Makassar City Hospital is only $15 \%$ and it is still found in some treatment units that do not return medical record documents on time with a percentage of $0 \%$. This is not in accordance with Permenkes 269 of 2008 with a maximum time of $2 \times 24$ hours or with a minimum standard of $80 \%$. In 2016 there were 73 incomplete medical record documents, in 2017 there were 88 incomplete medical record documents, in 2018 there were 98 incomplete medical record documents and in 2019 there were 22 incomplete medical record documents.

Completeness of medical records is very useful to know in detail the patient's medical history, examination actions that have been carried out, and to plan further actions. The diagnosis of the disease determined by a doctor will greatly affect the actions to be taken. The diagnosis of a disease determined by a doctor will greatly affect the actions of the patient in terms of treatment or even the actions to be taken.

Research related to the completeness of filling and returning medical records was carried out by Winarti and Supriyanto with the title Analysis of Factors Affecting the Inaccurate Time of Returning Inpatient Medical Record Files at X Hospital Bogor, which shows that where in the results it states that the number of inpatient medical records at hospitals in Surabaya only reaches $66 \%$. The compliance of health workers with their responsibilities in completing the medical documents filling form was $85 \%$. Meanwhile, only $58 \%$ of medical records were returned correctly, which was less than the same as 2 times 24 hours (Winarti, 2013). Previous research from Marutha (2017) stated that $15 \%$ of respondents stated that

Copyright (0 2020, Journal of Asian Multicultural Research for Medical and Health Science Study, Under the license CC BY-SA 4.0 
their medical record management was very bad. This happened because the documents returned were more than a month (99\%). In addition, it is known that the resources for medical record administration are inadequate (46\%), and $94 \%$ stated that they have never received any training related to policies and standards in managing documents. Returning medical record files will affect the process of providing services to patients.

Based on the description above, the researcher is interested in analyzing what factors influence the incompleteness and inaccuracy of returning inpatient medical record files at Makassar City Hospital seen from the knowledge of health staff, attitudes of health staff, SOPs, availability of medical record files, and work environment. This research aims to analyze the implementation of completeness filling and timeliness of returning inpatient medical record files at Makassar City Hospital in 2020.

\section{Methods}

This type of research is a mix method with a Cross Sectional Study approach. The study was conducted in August - September 2020. This research was conducted at the Makassar City Hospital. The sample of this study consisted of 87 files of patient medical records in the inpatient care room of Makassar City Hospital from 9 September - 9 October 2020. The sampling technique in this study was total sampling, so it has the same number as the existing population. As for the qualitative method consists of 5 informants whose selection technique uses purposive sampling.

The instrument used in data collection was the patient's medical record file. The items in the medical record file that were examined were the medical record number, patient identity, date and time, the results of the history, diagnosis, management plan, medication / action, observation notes, discharge summary, name and doctor's signature. Sources of data in this study are divided into two, namely primary data and secondary data. Primary data were obtained through in-depth interviews and observations of informants using interview guidelines. Secondary data were obtained from reviewing related documents which were used as supporting and complementary data from primary data for research purposes. The instruments in this study were in-depth interview guidelines, observation guidelines, documentation tools and notes in the field. Data analysis techniques are performed by reducing data, displaying data, transforming data, linking data, consolidating data, comparing data, and integrating data. Data presentation is presented in the form of brief descriptions, tables and charts.

\section{Results and Discussion}

This study discusses the percentage of completeness of filling in medical records and the timeliness of returning inpatient medical record files (quantitative) as well as incomplete and inaccurate factors in returning inpatient medical record files at Makassar City Hospital seen from the knowledge of health staff, the attitudes of health workers. , SOP, availability of medical record files, and work environment.

The implementation of completeness of filling in medical records is still relatively low, this can be seen from the most incompletely filled items, namely medical resume from 87 medical records, there are 39 medical records $(44.8 \%)$ that are not filled and 48 medical records (55.2\%) which is completely filled. Furthermore, in the Doctor Signature item, out of 87 medical records, 34 medical records $(39.7 \%)$ were unfilled and 53 medical records $(60.9 \%)$ were completely filled. Meanwhile, the completeness of filling in medical records for the part of patient identity, date and time, history taking, physical examination results and medical support, diagnosis, informed consent, and medical record number must be filled in completely (Table 1). 
Table 1. Distribution of Total Completeness of Completion of Items in the Medical Record Files of Inpatients at Makassar City Hospital

\begin{tabular}{|c|c|c|c|c|c|c|}
\hline \multirow[t]{2}{*}{ No } & \multirow{2}{*}{$\begin{array}{l}\text { Items in the Medical } \\
\text { Record File }\end{array}$} & \multicolumn{5}{|c|}{ Percentage of Completeness } \\
\hline & & Filled & $\%$ & $\begin{array}{c}\text { Not } \\
\text { Filled }\end{array}$ & $\%$ & Total \\
\hline 1 & Medical Record Number & 87 & $100 \%$ & - & - & $100 \%$ \\
\hline 2 & Patient identity & 85 & $97.7 \%$ & 2 & $3.3 \%$ & $100 \%$ \\
\hline 3 & Date and Time & 84 & $96.6 \%$ & 3 & $3.4 \%$ & $100 \%$ \\
\hline 4 & Anamnesse & 84 & $96.6 \%$ & 3 & $3.4 \%$ & $100 \%$ \\
\hline 5 & $\begin{array}{l}\text { Results of Physical Examination } \\
\text { and Support }\end{array}$ & 82 & $94.3 \%$ & 5 & $5.7 \%$ & $100 \%$ \\
\hline 6 & Diagnosis & 83 & $95.4 \%$ & 4 & $4.6 \%$ & $100 \%$ \\
\hline 7 & Informed Consent & 78 & $89.7 \%$ & 9 & $10.3 \%$ & $100 \%$ \\
\hline 8 & Medical Resume & 48 & $55.2 \%$ & 39 & $44.8 \%$ & $100 \%$ \\
\hline 9 & Doctor's Signature & 53 & $60.9 \%$ & 34 & $39.1 \%$ & $100 \%$ \\
\hline
\end{tabular}

Implementation of timeliness of returning medical record files for inpatients is still low and has not been fulfilled. Of the 87 medical records, there were 39 medical record files $(44.8 \%)$ whose return time to medical records was more than $2 \times 24$ hours and 48 medical record files $(55.2 \%)$ whose return time to medical records was less than $2 \times 24$ hours (Table 2).

Table 2. Distribution of Total Delays in Returning Medical Record Files at Makassar City Hospital in 2020

\begin{tabular}{|c|c|c|}
\hline Return Time & Amount & $\mathbf{( \% )}$ \\
\hline Less than $2 \times 24$ hours & 48 & 55,2 \\
\hline More than $2 \times 24$ hours & 39 & 44,8 \\
\hline Total & $\mathbf{8 7}$ & $\mathbf{1 0 0 , 0}$ \\
\hline
\end{tabular}

Implementation of completeness of filling and timeliness of returning medical record files in terms of knowledge of health workers. Based on interviews conducted in relation to special training for health workers in hospitals regarding filling out medical record files, it was stated that most of the informants had never attended training on filling out medical record files at Makassar City Hospital. While the knowledge of employees regarding the consequences of delays in returning medical record files, information was obtained that BPJS claims were slow to be paid. This was revealed from the following interview results:

"... If it's late noodles, late payment is the claim to the hospital. So the memnag has to do it on time, so be quick it's a claim ... "( $\operatorname{Inf} \mathrm{V}, 39$ years).

"... Medical records are important, deck. Actually, the medical record is important because it includes the patient's identity. In order to make it easier to handle and claim the BPJS tariff later. If it's too late to return it to the medical record, it's detrimental to the hospital too ... "(Inf XI, 49 years old)

Implementation of completeness of filling and timeliness of returning medical record files in terms of attitudes of health workers. Based on interviews conducted regarding the sanctions imposed for not filling in complete medical record files, it was found that the sanctions given were direct admonitions during a meeting with hospital leaders. This was revealed from the following interview results:

“... So if it is not complete, every month there is a list of doctors who have not completed their medical records, so they receive a warning, how many times, how 
many times. If not, that's okay. I don't know anything else, I have never been given a sanction... "(Informant III, Head of IRNA).

"... usually when there is a meeting, there is a direct warning from the medical service or medical committee ..." (Informant VI, Head of RM).

Efforts were made to overcome incomplete filling and delays in returning RM files, based on the results of interviews, namely monitoring and evaluating and reminding health workers in charge of filling in patient medical records.

Based on the implementation of completeness of filling and timeliness of returning medical record files in terms of SOP for medical records at Makassar City Hospital, there is an SOP on medical records. This is in accordance with the results of the document review. Meanwhile, the incompleteness and delay in returning the medical record files will result in the failure of the SOP that has been enforced by the hospital regarding the optimal implementation of medical records.

Implementation of completeness of filling and timeliness of returning medical record files in terms of availability of medical record files. A medical record file is available in hospitalization and at the time of providing services. Regarding the perception regarding the format of the medical record form, it is known that the format of the medical record form in the treatment room still needs to be revised, there are too many to write down, there are overlapping files. This was revealed from the following interview results:

"... as a doctor, in my opinion there are too many forms to fill in, but if the contents are the same as the previous form ..." (IV Informant, Doctor)

"... hehehe actually a bit dizzy, this is a medical record file, because it looks like an overlap, this one has been filled, right back to the next sheet with the previous sheet ..." (Informant V, Doctor)

Implementation of completeness of filling and timeliness of returning medical record files in terms of the work environment. The hospital has provided facilities and infrastructure for the implementation of medical records, but the need to add some facilities is still lacking. As for the expectations regarding the facilities used in filling out medical record files, namely medical record files that are even better than the current one. This was revealed from the following interview results:

"... for my treatment there is no problem for medical records, but it would be better if possible for the medical records to use such a sophisticated system, which does not have to write anymore, which can be directly via smartphone ta ..." (Inf V, Doctor)

The implementation of completeness of filling in medical records is still relatively low, this can be seen from the most incompletely filled items, namely medical resumes of 87 medical records, there are 39 medical records that are not filled This is in line with research conducted by Sri Ani (2017) which aims to determine the completeness of the contents of medical records on the medical resume form for surgical cases at Haji Pondok Gede Hospital, Jakarta, found that out of 40 medical records sampled were found below 40 (100\%). Incompletely filled medical resume. The results obtained were the Patient Identification component $100 \%$ important records $73 \%$ Author authentication $77 \%$ good notes $67 \%$. The cause of the incompleteness of filling out medical resumes at the Pondok Gede Haji Hospital in Jakarta is the level of compliance of doctors in filling out medical resumes, causing many medical resumes to not be completed immediately.

Incompleteness in filling out medical resumes can have an impact on the internal and external hospital because the results of processing medical resume data are the basis for making

Copyright @ 2020, Journal of Asian Multicultural Research for Medical and Health Science Study, Under the license CC BY-SA 4.0 
internal and external reports of the hospital, making decisions by leaders, especially evaluating the quality of services that have been provided to patients in the hope that the results of the evaluation will be better in making it will be better in making further treatment plans for patients, and to support orderly administration because it can result in delays in the insurance claim submission process. The quality of the completeness of the contents of the medical resume of surgical cases must be considered because it can be used as an assessment material by medical staff in ensuring the continuation of quality services and improving the quality of hospital services (Ani \& Viatiningsih, 2017)

Furthermore, in the Doctor Signature item, out of 87 medical records, 34 medical records were not filled. This is because doctors are in a hurry during the visite so that they delay filling out medical records because they have to go back to the polyclinic. This is in line with research conducted by (Mirfat et al., 2017) which aims to find out the problem of delays in returning inpatient medical record files at X Hospital. The main factor causing delay in returning inpatient DRM is the HR factor (human resources), namely the indiscipline of the DPJP (doctor in charge of services) in filling out medical records, especially medical resumes, some DPJP Don't visit every day so the advice goes home per phone and the nurse forgets to remind the doctor to fill out a medical resume and signature.

In Makassar City Hospital, the item name and signature on the medical record is filled in, someone writes the name of the doctor only but does not provide a signature as valid evidence that the doctor has examined the patient. When viewed from Permenkes No. 269 / Menkes / Per / III / 2008 it can be said that the item is incomplete because it has been explained that the item name and signature must be filled in both, not just one of them.

Meanwhile, the completeness of filling in medical records for the part of patient identity, date and time, history taking, results of physical examination and medical support, diagnosis, informed consent, and medical record number must be filled in completely. This shows that the main factor in the delay in returning the medical record files to the medical record installation is the incomplete filling of the patient's medical records. This proves that the completeness of medical records is still not getting enough attention in hospitals. This can be caused by various factors such as the number of patients who come for examinations so that doctors or other health workers do not have enough time to complete the medical record files because of the large number of patients who want to do the examination, this is also due to a lack of good communication between doctors. with medical records officers.

This is in line with research conducted by (Nurhaidah et al., 2016) which stated that the completeness of medical record files at the University of Muhammadiyah Malang Hospital was still very lacking, where out of 40 medical record files there was no complete filled file. This is due to the lack of doctor's attention to filling in medical record files completely, as well as the lack of time for doctors to fill in medical records. Medical record officers also have an important role in reminding doctors if the medical record files are still incomplete. However, this is not in line with the research conducted by (Ulum, 2013) which stated that the completeness of the medical record files at Bhayangkara Hospital Semarang was good enough. Of the 239 medical record files, only $14(6 \%)$ of the medical record files were not completely filled.

Implementation of timeliness of returning medical record files for inpatients is still low and has not been fulfilled. Of the 87 medical records, there are 39 medical record files whose return time to medical records is more than $2 \times 24$ hours. This is not in accordance with Permenkes 269 of 2008 with a maximum time of $2 \times 24$ hours or with a minimum standard of $80 \%$. This research is in line with the research conducted by (Winarti, 2013) which aims to determine the completeness and return of inpatient medical records at the hospital " $\mathrm{X}$ " in 
Surabaya. The results obtained from the 128 medical record files that were sampled were 95 medical record files $(69 \%)$ medical record files whose returns were more than $2 \times 24$ hours. Based on the results of this study, the cause of the delay in submitting medical record documents to the medical record installation was the low discipline of doctors who were responsible for filling in data on medical records. Returning medical record documents that are not timely can be a burden for officers in data management. Because the data obtained is already experiencing delays, the processing will also experience delays.

Implementation of completeness of filling and timeliness of returning medical record files in terms of knowledge of health workers. From the information obtained by researchers in indepth interviews, it was found that the implementation of special training for filling out medical records at Makassar City Hospital was not comprehensive for all health workers. Especially for medical record officers, the informant said that there had been training but only a few representatives were involved in the training. This is in line with the research conducted (Lony, 2015) regarding the analysis of the implementation of inpatient medical records at Sawahlunto Regional Hospital where there has never been any special training for medical record personnel by the hospital, only in the form of socialization and orientation not all officers have received it. Training in filling out medical records is very much needed for health workers to support the implementation of maximum health services. Therefore, the hospital needs to conduct training or workshops on medical records for all health workers.

The delay in returning the inpatient medical record files to the assembling department can interfere with services, especially if these documents are needed when the patient is about to undergo outpatient treatment or will be hospitalized again. This delay will certainly disrupt service continuity. Medical records in the JKN era are very important because they determine the cost for claims. According to Pujihastuti \& Sudra (2015) There are 65\% of hospitals that have not made a complete and clear diagnosis, including hospitals that are collaborating with BPJS. Interviews conducted by informants have found that the result of late return of medical record files is that claims for insurance have also been paid.

Implementation of completeness of filling and timeliness of returning medical record files in terms of attitudes of health workers. Regarding the sanctions given for not filling in complete medical record files, in Makassar City Hospital the sanctions given are direct warning during a meeting with the hospital leadership. This is not in line with the research at Dr. Kariadi Semarang who said that there was no strict sanction regarding the incompleteness of filling in inpatient medical record files. The purpose of imposing sanctions is to prevent the occurrence or repetition of a violation or mistake committed by an employee, for example in the case of delays in returning medical record files. Sanctions are raised for an employee who commits mistakes and violations in order to be motivated to stop deviant behavior and lead to positive behavior, so that the imposition of firm sanctions is expected to minimize the occurrence of incomplete filling of inpatient medical record files (Swari et al., 2019).

Regarding the efforts made to overcome the incomplete filling and delays in returning the RM file, by monitoring and evaluating and reminding the health workers in charge of filling out the patient's medical records. This is not in line with research at Dr. Kariadi Semarang who said that the incompleteness monitoring activity towards incompleteness was still not effective because the medical record officers who carried out monitoring had to go around entering all inpatient rooms (Swari et al., 2019).

Implementation of completeness of filling and timeliness of returning medical record files in terms of medical record SOPs. Based on the research results, it is known that the perceptions of health workers on the availability of SOP on medical records are readily available and have been socialized. But it's still not running optimally and is stored as a hospital file. 
According to the informant, the medical record SOP had been given to each treatment room, but it was only stored and not shown / displayed because the informant thought that health workers who had the right to fill in medical record documents had known how to fill in medical record documents. Fixed procedures are made when the hospital will be accredited and will be shown if there are parties who want to carry out research and routine hospital routine examinations.

Previous research conducted at RSJ Dr. Radjiman Wediodiningrat which aims to determine the impact of socialization of SOP returns $1 \times 24$ hours after finishing service using posters. The research instrument was a report on the assembling section of the medical record installation at RSJ Radjiman Wediodiningrat. The results showed that there was an effect of SOP socialization on the number of late medical records and did not have a significant effect on late inpatient medical records (Shinta Devi et al., 2016).

Implementation of completeness of filling and timeliness of returning medical record files in terms of availability of medical record files. The availability of medical record files at Makassar City Hospital has reached $100 \%$. This research is in line with research conducted at the Balung Regional Hospital which aims to increase the completeness of medical record files, showing that all respondents in the study considered that the respondents considered that the medical record format was always available when filling out medical records, namely $57.1 \%$ administrative officers, nurses. $71.7 \%$ and doctors $80 \%$. The clarity of the medical record format, which is the format of the medical record for respondents, feels clear in the filling, so that the respondent will fill in the medical record easily. In this study, respondents stated that the availability of medical files in providing services felt that they were good enough.

The suitability of the medical record form sheet is an assessment of the respondent on whether the medical record sheet is appropriate or not with what is recorded from a service to the patient. The existence of this conformity can make it easier to fill in medical records, so that medical record completeness can be faster (Wirajaya \& Nuraini, 2019). In this study it is known that all respondents gave a positive response to the availability of medical record files in inpatient care rooms.

Implementation of completeness of filling and timeliness of returning medical record files in terms of work environment. In the installation of medical records, additional computer facilities are still needed for employees, where the number of these facilities is not proportional to the number of staff in the room who will use them so that the use of facilities such as computers is carried out alternately. The results of observations made by the researchers showed that in the medical record storage room there was a medical record computer, but its function was limited. The medical record staff room is also still narrow so that the employee's desk is closely linked to the medical record file storage cabinet. Then in the registration or registration room, there is a registration process for patients with a chair, table and computer and a registration book.

This is in line with research conducted by (Syamsuriani, 2017) which aims to analyze the completeness of filling in and the timeliness of returning medical record files of inpatients at Dr. Wahidin Sudirohusodo is a material that supports the implementation of medical record services in order to run well, there is still a need for computer facilities in several work units in medical records, whose numbers must be proportional to the number of workers in the room who will use them so that the use of computer facilities is not used alternately.

Another similar study was conducted by (Mahendra, 2019) which aims to evaluate the implementation of inpatient medical records at Arosuka Hospital that the facilities and 
infrastructure in the implementation of medical records are still incomplete, such as computer needs are still not available enough, storage space is sometimes still incomplete.

\section{Conclusion}

The implementation of completeness of filling in medical records and timeliness of returning medical record files for inpatients is still low in Makassar City Hospital. The training for filling out medical records has not been fully implemented to all health workers (doctors and nurses) and medical record officers at Makassar City Hospital. The result of the delay in returning the documents is the late payment of insurance claims to the hospital. Accumulation of medical records in the treatment room results from incomplete medical records and is returned to the treatment room. The sanction for health workers who do not complete the medical records is a direct warning during a meeting. Availability of SOP on filling and returning medical record files and availability of medical record files. Facilities and infrastructure in the implementation of medical records are still insufficient, especially in medical record installations.

\section{References}

Ani, S., \& Viatiningsih, W. (2017). Tinjauan Kelengkapan Isi Rekam Medis Pada Formulir Resume Medis Kasus Bedah Di Rumah Sakit Haji Pondok Gede Jakarta Pada Tahun 2017. Junal INOHIM, 5(1), 64-69.

Hatta, G. (2008). Pedoman Manajemen Kesehatan di sarana pelayanan kesehatan. Jakarta: Penerbit Universitas Indonesia.

Leony, M. (2015). Analisis Penyelenggaraan Pelayanan Rekam Medis Rawat Inap Di Rumah Sakit Umum Daerah (RSUD) Sawahlunto. Available from: http://scholar.unand.ac.id/id/eprint/2612

Mahendra. (2019). Analisis Pelaksanaan Rekam Medis Pasien Rawat Inap di Rumah Sakit Umum Daerah dr. Rasidin Padang Tahun 2018. Fakultas Kesehatan Masyarakat Universitas Andalas. Padang, 7-15. Available from: http://scholar.unand.ac.id/42881/5/SKRIPSI MAHENDRA_FULL TEXT.pdf

Michaud, E., McClendon, M., \& Salzman, K. (2006). The tactical electronic medical record: The key to medical transformation. US Army Medical Department Journal, 56-65.

Mirfat, S., Andadari, N., \& Nusaria Nawa Indah, Y. (2017). Faktor Penyebab Keterlambatan Pengembalian Dokumen Rekam Medis di RS X Kabupaten Kediri. Jurnal Medicoeticolegal Dan Manajemen Rumah Sakit, 6(2), 174-186. https://doi.org/10.18196/jmmr.6140

Nugraheni, S. W., \& Hendratna, A. D. N. (2019). Accreditation Of Medical Records In Primary Cares. In Proceeding International Conference (Vol. 1, No. 1, pp. 747-752)

Nurhaidah, N., Harijanto, T., \& Djauhari, T. (2016). Faktor-Faktor Penyebab Ketidaklengkapan Pengisian Rekam Medis Rawat Inap di Rumah Sakit Universitas Muhammadiyah Malang. Jurnal Kedokteran Brawijaya, 29(3), 258-264. https://doi.org/10.21776/ub.jkb.2016.029.03.4

Pujihastuti, A., \& Sudra, R. I. (2014). Hubungan kelengkapan informasi dengan keakuratan kode diagnosis dan tindakan pada dokumen rekam medis rawat inap. Jurnal Manajemen Informasi Kesehatan Indonesia, 2(2), 60-64..

Shinta Devi, S., Sri Hidayati Rini, N., \& Hakim, L. (2016). Pengaruh Implementasi Standar Prosedur Operasional Pengembalian Rekam Medis di RSJ Dr. Radjiman 
Wediodiningrat Lawang. Jurnal Kedokteran Brawijaya, 29(3), 265-268. https://doi.org/10.21776/ub.jkb.2016.029.03.5

Swari, S. J., Alfiansyah, G., Wijayanti, R. A., \& Kurniawati, R. D. (2019). Analisis Kelengkapan Pengisian Berkas Rekam Medis Pasien Rawat Inap RSUP Dr. Kariadi Semarang. ARTERI : Jurnal Ilmu Kesehatan, 1(1), 50-56. https://doi.org/10.37148/arteri.v1i1.20

Syamsuriani. (2017). analisis kelengkapan pengisian dan ketepatan waktu pengembalian erkas rawat inap di RSUP DR. Wahidin Sudirohusodo Makassar. Thesis, Universitas Hasanuddin.

Ulum, M. C. (2013). Analisis Kelengkapan Pengisian Dokumen Rekam Medis Rawat Inap di Rumah Sakit Bhayangkara Semarang pada Periode Bulan Mei 2013. Thesis, Universitas Dian Nuswantoro Semarang.

Winarti, S. S. (2013). Analisis Kelengkapan Pengisian dan Pengembalian Rekam Medis Rawat Inap Rumah Sakit. Jurnal Administrasi Indonesia, 1, 345-351.

Wirajaya, M. K., \& Nuraini, N. (2019). Faktor Faktor yang Mempengaruhi Ketidaklengkapan Rekam Medis Pasien pada Rumah Sakit di Indonesia. Jurnal Manajemen Informasi Kesehatan Indonesia, 7(2), 165. https://doi.org/10.33560/jmiki.v7i2.225 